\title{
Present and Future Agricultural Extension System of Malawi*
}

\author{
Siliro Nkhukuzalira Magomero ${ }^{a}$ Duk-Byeong Park ${ }^{b^{* *}}$ \\ ${ }^{a}$ Ministry of Agriculture and Food Security, Government of Malawi (P.O. Box 30145, \\ Lilongwe 3, Malawi, Central Africa) \\ ${ }^{b}$ Department of Community Development, Kongju National University (54 Daehak-ro, \\ Yesan-gun, Chungnam, Republic of Korea)
}

\begin{abstract}
Malawi's agricultural extension system has been subjected to a number of criticisms in recent times for failing to contribute significantly to agricultural development and for not responding to the needs of the smallholder farmers. Despite this, extension is still seen as key to improving poverty and rural livelihoods. There is a number of challenges facing extension that require a response from the public sector and other stakeholders. A clear and positive response to these challenges will help shape the future of agricultural extension in Malawi for the benefit of all farmers and the attainment of the broad policy objectives of government: democratization, market liberalization, decentralization,
\end{abstract}

* Paper prepared to be presented at the International Symposium on the Systems and Development Strategies of Agricultural Extension of the World in November 2013, Jinju, South Korea

** Corresponding Author (Duk-Byeong Park) e-mail: parkdb84@kongju.ac.kr 54 Daehak-ro, Yesan-gun, Chungnam, Republic of Korea 
HIV/AIDS crisis, shrinking public sector resources, public sector reform, and co-ordination, etc. The mission is to provide pluralistic demand driven extensions services and promote equalisation and co-ordination in service provision in order to achieve food security at household level, there-by reducing poverty. On the other hand the vision is that 'All farmers' demand and access high quality extension services from those best able to provide them'. DAES implements its extension policy through the District Agricultural Extension Services System (DAESS), based on Model Village Approach.

Key words: Agricultural Extension, Malawi

\section{INTRODUCTION}

Future success of rural development efforts in developing countries will depend not only on the presence of technical expertise and availability of resources but also on each government's willingness to redefine the role of its institutions and to allow the active participation of rural people in formulating and implementing rural development programmes (Swanson \& Samy, 2002). As partners in development, public extension systems in developing countries are under increasing pressure to prove their relevance and importance.

The original inhabitants of Malawi were the Bushmen. However, the country was letter occupied by Bantu speaking people starting from the First Century A.D Malawi was previously known as Nyasaland Protectorate under the British colonial administration. Formal declaration as a protectorate was made in 1891 with Sir Harry Johnston as first 
Governor. Some white settlers had settled in the country as back as 1875 when the negotiated with Chiefs who gave them large pieces of land on which they grew their crops such as cotton, coffee as cash crops and mainly maize as food crop.

At this moment, the so called African/indigenous farmers were growing crops on subsistence basis and were not receiving any agricultural extension advice because no extension system existed. This paper explores agricultural extension systems, extension challenges, research and extension models, governance structures of agricultural extension and advisory services in Malawi.

\section{AGRICULTURAL EXTENSION SYSTEMS IN MALAWI}

Malawi's agricultural extension system has been subjected to a number of criticisms in recent times for failing to contribute significantly to agricultural development and for not responding to the needs of the smallholder farmers. Despite this, extension is still seen as key to improving poverty and rural livelihoods.

The development of extension systems in Malawi has undergone three distinct phases. The first phase was during the colonial period, second during the one party rule and third, which is the current one is under the democratic rule. 


\subsection{First Phase: Colonial Period}

In 1903, the Government introduced some sort of organised agricultural extension service and was mainly for the estate farmers requiring higher productivity of their cash crops. Then the Department of Agriculture was established in 1907 (MOAI, 2000). 1) In the year 1948/1949 there was worst drought and feminine in Malawi history and the government though it wise to review its policies in general agricultural production and extension in particular. Consequently, in 1950, six agricultural policy objectives including those affecting extension were introduced as follows;

* Establish a National agricultural extension and training system

* Establish a national soil and water conservation programme

* Provide credit and subsidies to farm inputs

* Introduce regulations governing marketing of agricultural produce

* Establish agricultural projects and settlement schemes

* Establish new and strengthen existing agricultural research institutions that focussed on applied research.

In this regard, Government developed a more coherent national extension and training system that were organized into five tiers, namely: National, Regional, Divisional, Area and Sectional levels.

The approach used was mainly regulatory involving individual contact methods. The main focus was on cash crops (e.g. tea, tobacco

1) MOAI. 2000. Agriculture in the new millennium: towards pluralistic and demanddriven services in Malawi. Policy document. 
or cotton) and soil and water conservation. For smallholder farmers, the emphasis was regulatory - coercing them to conserve their land through agricultural laws. Violation of these laws resulted in court sentences which ranged from payment of fines to imprisonment. This resulted in the wholesale adoption of ridging in Malawi, as the major soil and water conservation strategy.

Later, the concept of master farmers was introduced in the extension system (Chibwana, 1998).2) Extension staff focused on a few master farmers and communities who were responsive to the recommended practices. Under this scheme, agricultural officials persuaded the master farmers to follow certain prescribed conditions of farming that included the farm's layout, rotation, soil conservation, methods of cultivation and animal husbandry. The extension programme encouraged master farmers by giving them training, free and subsidised inputs or a cash bonus after demonstrating a high managerial standard. In addition, the programme allowed master farmers to grow important cash crops such as tobacco and cotton. Leaders of the progressive communities also benefited. Later, it will be clear that the master farmer concept is still effective today, its application modified to suit the participatory extension approach conditions. A cooperative programme was introduced in 1948 to enhance agricultural production. The cooperatives were involved in input supply, commercial crop production, dairy farming and marketing. However, this programme did

2) Chibwana, C. 1998. A study of the agricultural extension programme in Malawi based on the staff and farmer's perspectives. La Trobe University, Melbourne, $\mathrm{PhD}$ Thesis, 1998. 
Siliro Nkhukuzalira Magomero • Duk-Byeong Park / Present and Future Agricultural

not make headway because it was banned early during the one party rule for political reasons. The democratic era has seen a return of cooperatives and associations, as a means to empower farmers.

\subsection{Second Phase: One-Party Rule}

Soon after independence, the government developed its own public extension system which moved away from the regulatory colonial extension system to a more user-friendly advisory service. The aim was to reach as many smallholder farmers as possible. The agricultural policy changed from soil conservation in the colonial era to commercialisation, focusing on inorganic fertilisers. Soil and water conservation measures received little attention, as this was one of the hot political issues among smallholder farmers during the fight for independence. The master farmer concept continued to be implemented and became part of the mainstream extension activities through the Achikumbe (progressive farmers) programme. The Achikumbe farmers were role models in their areas and assisted extension workers to demonstrate recommended agricultural practices. Alongside the master farmers' concept, extension workers organised farmers into groups for extension as well as credit activities, which was a welcome development at a time when integrated rural development projects called Major Projects were established across the country; Lilongwe Land Development Project (LLDP) in 1968, Shire Valley Agricultural Development Project (SVDP) in 1969, Karonga Rural Development Project (KRDP) in 1972 and Lakeshore Rural Development Project 
(LRDP) in1968. Mass media methods were intensified through production of print materials, radio programmes and use of mobile vans.

The Achikumbe programme and use of groups continued throughout the 70s and 80s until when it was discovered that it was only reaching the specialized groups, leaving out the majority of farmers. However, the group approach was officially sanctioned in 1981 based on the "Block Extension System" (BES), and adapted a training and visit (T\&V) extension system. Thus, from 1981-1993 a concept of National Rural Development Programme (NRDP) emerged from lessons learnt from the major projects where we have 8 Agriculture Development Divisions (ADDs) namely; Karonga, Mzuzu, Kasungu, Salima, Lilongwe, Machinga, Blantyre and Shire Valley. The BES was implemented across the country with the aim of expanding the group approach beyond the specialised groups in an attempt to reach the resource poor farmers and women. But, during the early 1990s the BES was heavily criticised as favouring the progressive farmers at the expense of the majority of smallholder farmers who were resource poor and women. The adoption rate of the recommended inputs such as the inorganic fertilisers and high yielding varieties of maize continued to be poor.

\subsection{Third Phase: Democratic Rule (The Present and Future)}

Agricultural Services Project (1994-2000) plus Pluralistic and Demand- Driven Agricultural Extension Services (2000 to date) 
Siliro Nkhukuzalira Magomero • Duk-Byeong Park / Present and Future Agricultural

With the advent of multiparty politics in Malawi in 1994 that gave ordinary Malawians such as smallholder farmers a voice, the public extension system that was based on the top down approach could no longer hold. The credit scheme that was the hub of agricultural extension service collapsed. Farmers became frustrated and lost interest in extension activities.

At the same time, there was a proliferation of Non-Governmental Organisations and other players, which took an active role in the provision of agricultural extension service that was the prerogative of the Ministry of Agriculture during the colonial as well as the one-party rule. The new NGOs introduced new approaches to extension and new ways of dealing with farmers, which were sometimes inconsistent with what the government was doing.

Agricultural markets were liberalised and decentralisation processes introduced. The new environment necessitated a review of the BES and eventually the extension policy. A new extension policy was therefore developed in 2000 focusing on pluralistic and demand driven extension services (MOAI, 2000)3) and giving rise to participatory approaches. Guidelines for implementing the extension policy based on the district decentralised service were also developed (MOAFS, 2004).4) MOAFS has an overall responsibility for coordinating extension service.

3) MOAI. 2000. Agriculture in the new millennium: towards pluralistic and demanddriven services in Malawi. Policy document.

4) MOAFS. 2004. District agricultural extension services system implementation guide: promoting pluralistic, demand driven and decentralised agricultural extension services in Malawi. 
However, there are key challenges facing extension that necessitated the development of the new extension policy:

\section{EXTENSION CHALLENGES}

There are a number of challenges facing extension that require a response from the public sector and other stakeholders. A clear and positive response to these challenges will help shape the future of agricultural extension in Malawi for the benefit of all farmers and the attainment of the broad policy objectives of government. The following are among the key challenges facing extension:

Democratisation;

* Market liberalisation;

* Decentralisation;

* HIV/AIDS crisis;

* Shrinking public sector resources;

* Public sector reform;

* Co-ordination;

* Difficulty to assess extension impact:

* High malnutrition levels among the farming communities;

* Low literacy level of farmers; and,

* Shrinking production resources. 


\subsection{Democratisation}

Democratisation, which has swept Africa in the recent past, has not spared Malawi and as a result society is opening up. People know that to survive they have to be proactive and thus farmers are demanding more from the public sector. For extension services, this is a new challenge because in the past there were fewer demands on the service and the mode of extension did not generate an open, critical response from the people. This requires extension services to reform their approaches in order to respond or deal with the numerous demands effectively.

But the democratisation process is clearly an opportunity for extension to get back to its roots. Democratic principles are at the heart of good extension. Extension services, now more than ever before, have a chance to contribute to the democratic transformation of society on the assumption that people will be more open to interact and share ideas.

\subsection{Market Liberalisation}

In addition to democratisation, market liberalization has seen the emergence of new players. Farmers are not restricted as to which crops to grow, livestock to keep or which markets to sell their agricultural products to. This has given the farmer greater choice, but in order to take advantage of market liberalization; farmers need new skills not only in production, but also in farm management and 
marketing. The new demands bring fresh challenges for those who provide agricultural extension especially that there is inadequate capacity among farmers to absorb changes due to inadequate managerial skills and limited land resource. At the same time market liberalisation assumes that market infrastructure is available.

Many farmers can benefit from the new opportunities, but unless something is done, some farmers will not participate in the market economy. The challenge for extension is, therefore, to become more specialised and diverse at the same time in order to respond to the new requirements of farmers and the sector as a whole. Expertise must be available to people who want to deal with specialised products but at the same time it is in the public interest to provide also for those in danger of lagging behind.

\subsection{HIV/AIDS crisis}

The HIV/AIDS pandemic in Malawi is having a serious negative impact on the productivity of the agricultural sector, the very backbone of Malawi's economy. Firstly, the impact is felt through the reduction of the productive work force, both among extension staff and the farming community. Practically all the key work force classes in agriculture are HIV/AIDS infected. In 1998 it was found that about 18 per cent of farmers and 12 per cent of the professional and skilled labour force were reported with AIDS. Apart from the human tragedy this also has cost implications in labour turn over, health care, HIV/AIDS absenteeism, recruitment, funeral functions and productivity 
loss after training. The demographics of the farming community are changing with increased numbers of households headed by children and old people. The challenge to agricultural extension is firstly, to maintain a healthy, energetic human resource both in the extension services and in the farming community, and, secondly, to prevent further spread of HIV/AIDS.

This requires integration of HIV/AIDS mitigation measures in the agricultural development programmes on the assumption that a healthy nation is a productive nation. The programme on factoring HIV/AIDS awareness in agriculture should therefore be strengthened. The intensification of labour saving technologies will help to reduce the drudgery on the farming population. The types of training and advice offered must take account of the changing demography. Greater attention also needs to be given to HIV/AIDS and agricultural education in schools at primary and higher levels. This requires building co-operation with agencies in the health and education sectors in the fight against HIV/AIDS crisis. Staff in the Ministry of Agriculture and Irrigation will also need HIV/AIDS education.

\subsection{Decentralisation}

With the coming in of the new democratic dispensation, government has decided to devolve power to the district level on the assumption that interventions are more effective when the decision making process is at the lowest level of action. The Ministry of Local Government, which has been charged with decentralisation, is calling for the 
participation of line ministries. Decentralisation is an opportunity to bring the control of extension closer to the people and offer services that fit better with the local situation. But this will bring a dramatic shift in roles and responsibilities. The present capacity at the district level, as far as agriculture is concerned, is not adequate to cope with increasing demands for every District Assembly to have quality staff. There is, therefore, a big challenge to enhance both the technical and management expertise at the district level in order to deal with increased demands.

\subsection{Shrinking public sector resources}

Financial and human resources available to the public extension service in Malawi are shrinking. In real terms, funding from government coffers to the public extension service has been decreasing since 1990. During the same period, there has also been decreasing numbers of staff in the public extension, leaving the service with lowly trained and inexperienced staff to execute public extension programmes. There has been erosion in technical expertise that, together with the financial situation, makes the public service largely ineffective and unsustainable. This has also caused a reduction in staff morale as a result of inadequate operational funds. Farmers are not getting the services they need and deserve on the understanding that poorly resource endowed extension service cannot effectively deliver.

To respond to the challenge there is need for the public extension service to exercise greater accountability, transparency and 
prioritisation for every aspect affecting the discharge of its responsibilities. Once mechanisms ensuring such attributes are in place, the few staff available will be more motivated to deliver high quality services than at present. Decentralisation and greater farmer control of their destiny will both contribute to the necessary improvements. Furthermore, promoting pluralism through the mobilisation of other extension providers from the private sector, the non- governmental organisation (NGO) community and farmer organisations will also help respond to the challenge of shrinking public resources.

\subsection{Public sector reform}

The public sector reform programme, that the Government of Malawi is currently undertook called for downsizing and streamlining of public agencies on the assumption that a well-trimmed organization becomes more effective and efficient. Ministries and government departments reduced their numbers of staff and streamlined their roles and functions. On the other hand, extension services in Malawi are highly dependent on the very public service delivery channels that shrunk. Thus there is a danger that services may become even more inaccessible to many farmers than before, with fewer experts who will face higher demands arising from such influences as the democratisation process. The opportunity to promote a greater role of other actors and agencies, particularly farmer organisations, in the provision and delivery of extension services must be seized. Thus 
public agencies with a mandate for functions related to extension must take up a role of facilitator and co-ordinator rather than service deliverer.

\subsection{Co-ordination}

Since the early 1990s there has been an increased number of stakeholders involved in extension, making co-ordination of extension service activities a growing challenge. There are now more farmer organisations, NGOs and pri- vate sector agencies, often with different approaches for the delivery of extension services. The lack of co-ordination means that donors tend to introduce approaches of their choice. It has been a challenge to maintain coherence and quality in the delivery of extension services in Malawi. In order to improve co-ordination among the many stakeholders in extension there is need to have clear policy guidelines to orient all stakeholders towards complementarity and synergy in the roles they play in the provision and delivery of extension services.

Co-ordination needs to be stratified. A key level for co-ordination will be at the district level, working towards joint planning and implementation of extension services among various stakeholders. There is also need for co-ordination at the national level. Diversity and pluralism (i.e. having more extension service providers on various issues and using different methods) need to be embraced, but complemented by effective co-ordination that brings about coherence and partnerships based on common guiding principles. 


\subsection{Difficulty to assess extension impact}

Extension services are only one factor contributing to agricultural development. There is many other economic, policy, environmental and social factors that add to the problem of attributing either successes or failures to extension. The impact of extension is also often not immediate. Furthermore, there are often different procedures and approaches used in extension services which add to the complication of tracing cause and effect in the performance of different extension approaches. This partly results in the public extension service being perceived by many as a low class service that does not need adequate funding and highly trained staff. It is difficult to maintain the necessary political will, commitment and budgetary support as impact in, for example, infrastructure projects are much more observable. As a result, the public extension service is regarded as less credible in the public eye.

Concern for quality and efficiency makes it imperative that impact can be plausibly traced. Greater farmer involvement in the control and assessment of extension services will be one means for responding to this challenge. In addition, product specialisation, where possible, can also help improve the monitoring and evaluation of activities. Linked to this, privatisation of extension services will ensure constant and spontaneous feedback through improved private sector relationships with client farmers. 
3.9. High malnutrition levels among the farming communities

The high levels of malnutrition among the farming communities are a serious challenge to the extension delivery service. Well-nourished farmers can undertake effective agricultural activities. Malnutrition is visibly shown in under-five children, 48 per cent of whom become stunted due to malnutrition. Others suffer from both mental and physical impairment. Considering that they are the future farmers, there is no doubt that their impairment affects their effective agricultural productivity. As the majority of Malawi's population live below the poverty line, malnutrition would also be prevalent. Those in the rural areas who cannot feed themselves throughout the year spend most of their time during the critical period of farm activities working for others for cash or food. The consequence is that they are less productive because they are malnourished and produce less of their own food for the following year.

\subsection{Low literacy level of farmers}

Malawi is among the countries that have low literacy levels in Africa. It is estimated that male literacy level is at 48 per cent while that of females is at 29 per cent. This is a big challenge to the extension service in the sense that literate farmers understand better the technologies that they discuss with the extension service providers. In the light of low literacy levels among farmers, technology adoption becomes lower and consequently affects effectiveness of the 
extension service. Effective agricultural productivity goes beyond increased farm produce; farmers must operate like entrepreneurs. To farm like a business person, the farmer requires education of some kind; she/he needs to make calculations and decisions that call upon reasonable literacy levels.

\subsection{Shrinking production resources}

Farmers face challenges because of shrinking production resources such as land, capital and labour. Smallholder farm land has been shrinking due to increased population and fragmentation of land among family members. Considering that most smallholder farmers are less productive due to the use of unimproved agricultural practices, the small hectarage does not sustain their livelihood. Most smallholder farmers are poor and do not have adequate capital for effective farming. Worse still they do not have access to credit due to lack of collateral. In such circumstances agricultural productivity is bound to be low. Poverty drives most smallholder farmers to hiring out their scarce labour to wealthier farmers during the critical period of agricultural activities. This situation aggravates the availability of labour resource. The extension service faces challenges to improve productivity of such farmers who have these shrinking production resources.

The first step in making a response to these challenges is to have a clear vision of agricultural extension in Malawi as a basis for managing positive change. 


\section{MISSION AND VISION OF THE DEPARTMENT OF AGRICULTURAL EXTENSION SERVICES (DAES)}

The mission is to provide pluralistic demand driven extensions services and promote equalisation and co-ordination in service provision in order to achieve food security at household level, there-by reducing poverty. On the other hand the vision is that 'All farmers' demand and access high quality extension services from those best able to provide them'.

DAES implements its extension policy through the District Agricultural Extension Services System (DAESS), based on Model Village Approach (MoAFS 2004). Booklets containing the guidelines for implementing the system were published and distributed to all extension staff. The guidelines stipulate that the extension system and the model village approach are aimed at promoting participatory principles for the creation of demand-driven extension services whereby farmers are empowered to identify problems and establish priorities according to their needs.

Under the new extension policy, the mandate of DAES is to

- Coordinate agricultural extension activities for all technical departments of MoAFS.

- Institutionalize a decentralized agricultural extension service system in all districts.

- Develop and disseminate agricultural extension messages.

- Enhance research/extension/farmer linkages. 
- Coordinate formation and management of farmer organizations.

- Enhance mainstreaming of gender and HIV/AIDS issues in all agricultural programs.

- Enhance agribusiness knowledge and skills in staff and farmers.

- Enhance community nutrition knowledge and skills in staff and farmers.

To implement this extension system effectively, DAES has five technical branches:

1) Extension Methodology and Systems

2) Agriculture Communication

3) Agribusiness Development

4) Food and Nutrition

5) Agriculture Gender Roles

According to MoAFS (2004), the DAESS translates the extension policy into practice using two main structures: The stakeholder panels at the district and area levels and the District Agricultural Extension Coordinating Committee (DAECC). The two structures are tools for integrating the agricultural extension system into the district assembly. The stakeholder panel represents all actors in the agricultural sector, which include farmers, farmer organizations, and NGOs. The major roles for stakeholder panels are to provide a forum for dialogue where farmers can demand service directly from both private and public service providers and ensure that the quality and standards of the 
service are maintained.

These panels are facilitated by the DADO and Agricultural Extension Development Coordinator (AEDC) at the district and area levels, respectively. The district extension system has been established in all districts and, if strengthened, it has potential to develop into an effective partnership in the provision of extension in agriculture. The DAECC is critical if the pluralistic extension system is to be effective. However, the extent to which the structures are functioning is not clear. As it will be shown in this study, a lack of or poor coordination among the stakeholders is one of the challenges in the provision of extension services in Malawi.

The DAECC is comprised of DAES officials and other agricultural extension service providers in the private sector, such as NGOs and farmer organizations. Its major role is to coordinate extension service delivery in the district assembly and ensure that the quality and standards of the extension service are controlled.

The district agricultural extension system rests on four pillars (MOAFS, 2004):

- Organization of farmer demand: Extension staff members are encouraged to organize farmers based on their categories and respond to their needs and problems accordingly. MoAFS categorizes farmers into three groups based on their resource endowments and socioeconomic status:

a) Commercial farmers $(\mathrm{CFs})$ : These are economically active on a large scale, with farm enterprises such as tobacco, maize (seed and food), tea, coffee, and dairy. 
b) Small-Scale Commercial (SSC): These farmers have attained food security, possess commercial and market orientation, and are skilled in the specialist enterprises such as tobacco, horticultural crops, rice, paprika, spices, and dairy.

c) Smallholder food security (SHFS): These are farmers who possess the potential to achieve household food security from agricultural production on their farms, but due to limited land and resources are unlikely to produce a surplus for the market.

- Emphasis is on SHFS farmers, who represent 80 percent of the smallholder farmers. In view of the top-down approach that has characterized the public extension system for decades, this pillar calls for a change in attitudes by both extension staff and farmers to allow for dialogue that will facilitate a responsive, demand-driven extension system (MoAFS, 2004).

- Facilitation of service provider response: This pillar focuses on the need for the DAECC to coordinate extension services in the district and ensure that the services respond to the needs of all farmer categories. It identifies who is doing what and where in terms of extension service provision in the district and works to reach agreement on how best to utilize the available resources.

- Coordination and agricultural strategy development: This calls for the development of an agricultural strategy for the district in view of the many players in extension service delivery with different approaches and methods. A coordinated strategy helps minimize conflicts that may bring confusion among farmers.

- Funding acquisition: In response to dwindling public resources for 
the delivery of extension services, this pillar encourages extension providers to maximize the available resources from different stakeholders in the district as well as work to source more funds for the benefit of the farmers.

\section{RESEARCH AND EXTENSION MODELS AND APPROACHES}

This section reviews the three basic research and extension models that have been used as the extension system evolved. It will show how these influenced agricultural productivity and livelihoods of smallholder farmers. The models are: transfer of technology (TOT), Farming Systems Research and Development (Modified) TOT, and Participatory (farmer based). Although the models are discussed as distinct models, in practice, they constitute prototypes or umbrella terms that exist on a continuum based on degree of farmers' involvement in the process.

\subsection{Transfer of Technology (TOT) Model}

TOT is the traditional model based on the development of new agricultural technologies on research stations, followed by the transfer of this technology to extension services to transmit to would-be clients (Chambers and Ghildyal, 1985).5) In this model, agricultural 
Siliro Nkhukuzalira Magomero • Duk-Byeong Park / Present and Future Agricultural

research priorities are determined by scientists and by funding agencies. Technology transfer involves a top-down approach that delivers specific recommendations to farmers about the practices they should adopt. Examples include the development and dissemination of high yielding varieties of maize, rice and wheat that contributed to the green revolution of the 1970s. The technologies enabled large farmers to increase productivity and profitability, hence the green revolution. This top down approach is common among most public extension systems responsible for agriculture. The extension agenda is usually determined at national level with the primary goal of increasing production for exports and national food security. The basic assumption is that "good" technologies are available but farmers are not adopting them due to ignorance. The response therefore has been to improve the extension service by using better ways of dissemination (BES and group approach) in order to increase coverage.

The TOT model has, until in the 80s, been the dominant model used by almost all professionals concerned with agricultural research and extension worldwide. This model aims at a widespread adoption of technologies and tends to be successful in relatively homogenous, low-risk, natural and social environments, where farmers live under similar conditions, perceive the same kinds of challenges and share a common set of beliefs and values (Probst and Hagmann, 2003).6) But,

5) Chambers, R. and Ghildyal, B. P. Agricultural research for resource poor farmers: the farmer-first and last model. Agricultural Administration 20: 1-30, 1985.

6) Probst, K. and Hagmann, J. 2003. Understanding participatory research in the context of natural resource management-paradigms, approaches and typologies. ODI-AGREN Network Paper No. 130. accessed 14 ${ }^{\text {th }}$ November 2009. 
it is now clear that smallholder farmers in Malawi are not a homogeneous category.

The TOT model has had limited success with poor farmers in developing countries. The model assumes that the technology generated is good and appropriate to the farmers concerned. In practice however, it has been shown that the TOT model presented problems with poor farmers. When the poor farmers did not adopt the new technology, both social scientists and agricultural scientists at first attributed this to ignorance. That is, the poor farmers did not know about it, or did not know enough about it. The solution was then to improve on extension, more coverage and better ways of dissemination. According to Chambers, the common phrase was: "we must educate the farmer", which reflected underlying pattern of thought that "we have the relevant knowledge. Ignorant farmers do not have it. We must teach the ignorant farmers". However, researchers develop technologies with a particular target group or farming system in mind. As such, the verification trials are done in those specific areas and with those particular farmers. The technologies cannot therefore be expected to suit all farmers. Ironically, this line of thought still dominates the research and extension processes today.

\subsection{Farming System Research and Development (Modified TOT) Model}

In response to the problems associated with the transfer of technology to poor farmers, some modifications were made to the TOT model by involving the farmers so that researchers better 
Siliro Nkhukuzalira Magomero • Duk-Byeong Park / Present and Future Agricultural

understand the problems experienced by farmers in adapting and adopting their recommendations. This process showed that almost always farmers obtained lower yields than that obtained by the researchers due to biological and socio-economic constraints. For example, farmers tend to use inputs and practices that result in lower yields than the potential ones. The TOT model was therefore modified, giving rise to a farming systems research and development model. The model emphasised more on farmers' participation so as to understand better their complex situation and the interrelationships among elements of farming systems in order to adapt the technologies (Rhoades and Booth, 1982).7)

However, in the modified TOT, the research comes first to develop the technology that researchers later adapt and perfect following experience with its use in on-farm conditions. On-farm trials and demonstrations have now become part of the research and extension process in Malawi. A technology does not get out to farmers without these on-farm trials and demonstrations. But as stated earlier, a technology is developed with particular target group in mind although extension workers may disseminate it as a blanket recommendation.

The modified TOT model gave rise to two major extension approaches: the farming systems research and development and Training and Visit (T\&V). In Malawi, the Ministry of Agriculture attempted to establish the farming systems approach with its Department of Agricultural Research during the 1990s but was

7) Rhoades, R.E. and Booth, R.H. 1982. Farmer-back-to-farmer: a model for generating acceptable agricultural technology. Agricultural Administration, 11, 127-137. 
unsuccessful. However, the Ministry successfully established a modified T\&V system (BES) throughout the country. The BES focused on the improvement of farming in general to increase production for exports as well as national food security in the NRDP. The system was financially supported by the World Bank and aimed at responding to farmers needs and increasing coverage of the extension service beyond the specialised groups such as the credit farmers to include resource poor farmers including women.

As typical of the T\&V system, the BES places emphasis on the organisation of extension. It determined a rigid work and time schedule for all extension workers at grassroots level. Extension personnel received regular training and concentrated on those specific measures that they understood well. The BES has a number of operational features concerning the blocks, field visits, extension messages, staff and farmer training, and programme planning and evaluation. These features guide the extension staff when implementing the extension programme. The BES requires field assistants to divide their sections into eight sub-sections called blocks, thus the name Block Extension System. Basically, the block was the centre of extension activities.

The MoA introduced the BES in Malawi in response to a major criticism of Integrated Rural Development Projects (IRDPs), which emphasised the better off farmers at the expense of the poor farmers who were in the majority. The projects increased production at the expense of the majority of smallholder farmers who had no access to credit and extension services. To avoid these problems, the BES was 
Siliro Nkhukuzalira Magomero • Duk-Byeong Park / Present and Future Agricultural

to stress on the teaching of appropriate technologies to different target groups of smallholder farmers, encourage cooperation with other service providers, and emphasise linkages with agricultural researchers and farmers. The aim was to help the extension programme increase outreach beyond the credit farmers and specialised groups to include the poor and women farmers who were in the majority.

However, despite modifications to involve farmers in the development of technologies, the basic TOT structure remained unchanged. The outcome, in terms of adoption of new technology by the poor farmers did not change much. The focus was on farmers who have more resources than the average farmer, and were better placed to benefit from the technology generated. Thus, even the modified TOT has not responded well to the needs of the poor farmers, and does not encourage researchers to learn from farmers. As a result, the BES failed to increase coverage beyond the better resourced farmers and adoption did not increase much. The major problems associated with the BES included the following:

- The focus of the extension messages was on high yielding varieties of cash crops, including hybrid maize which were found to be inappropriate for the majority of the farmers who were the poor and women.

- Focused on credit farmers who were better resourced than the average farmer and therefore tended to take advantage of the recommended technologies. In the process, it neglected the resource poor farmers and women who were the majority.

- Low attendance of farmers at extension meetings as a result of 
the issues above.

- Financially, the BES requires a heavy investment to cover training and supervision costs. It is therefore unsustainable without donor support.

Nevertheless, rudiments of the BES are evident in the present extension system.

\subsection{Participatory Model}

The problems associated with the TOT model and its modified version led experts to question the research processes that generate agricultural technology rather than focusing on the farmers' environment. This led to the development of participatory approach model in which the farmer is the key element. The model has given rise to a number of participatory extension approaches summarised under "farmer first" where the emphasis is on the farmer such as Farmer-back-to-Farmer, Farmer First and Last, Farmer Participatory Research, and Participatory Technology Development (Probst and Hagmann, 2005).

The essence of the participatory model is that it does not assume that the technology generated is always good. When farmers do not adopt a technology, the model looks at the technology critically, as well as the research process that generated it, instead of concluding that farmers are ignorant. The model encourages research and extension staff to continuously work with and learn from farmers, as well as conduct research on-farm and with farmers. The main 
Siliro Nkhukuzalira Magomero • Duk-Byeong Park / Present and Future Agricultural

outcome expected from participatory model is the generation and adoption of appropriate technologies by the resource-poor farmers in response to their constraints in order to increase agricultural productivity and income (Probst and Hagmann, 2005). In this respect, the public extension system has experimented the following in a haphazard manner:

Participatory Extension Methods:

These are methods and tools that aim at promoting dialogue between the extension worker and the farmer. Under this umbrella, a number of tools and methods were introduced. The most common was the participatory rural appraisal (PRA), which introduced tools such as village mapping, transect walks, venn diagrams, and action plans. Other tools introduced in specific areas were the diagnostic grid, priority setting, strategic extension campaigns and priority setting among others.

Farmer Field Schools: a participatory approach which provides farmers with an opportunity to validate recommended technical interventions in their own fields. Farmers also share their farming experiences to learn and understand basic ecological principles behind the technical recommendations through study fields. It was introduced through an FAO initiative aimed at acting as an alternative to traditional, top-down agricultural extension in the specific context of Integrated Pest Management (IPM). Farmer empowerment is emphasised to build farmers' capacity to test and implement the interventions being recommended. This was introduced in specific areas where the extension workers were trained. 
Village level participatory approach: introduction of this approach was aimed at institutionalising the participatory approach in the MOA and other organisations involved in rural development. As such, it is not limited to agriculture although the MOA was instrumental in its introduction. It is designed to assist village communities to analyse their existing situation, identify and agree upon priority problems, make action plans to address the priority problems, take charge through their own organisations of the implementation action plans, and put pressure on the different service providers needed. The approach met challenges in terms of funding and coordination. As a result, it did not go further than the pilot areas.

\subsection{The Model Village Approach}

The model village approach is the major participatory approach being promoted through the District Agricultural Extension Services System. It promotes a participatory and multi-sectoral approach to planning, implementation, monitoring and evaluation of developmental programmes in a specific locality (one or more villages). The approach encourages staff to involve farmers in the extension process and thereby empower communities - enabling them to better articulate their demands (MOAFS, 2004). In this approach, a village is recognised as the entry point for all agriculture related programmes under the decentralised district agricultural extension system. A village has well-defined leadership and norms governing the inhabitants. Joint planning and implementation of programmes at this level is 
encouraged by the Ministry, as it ensures consolidated efforts by stakeholders in terms of mobilisation and utilisation of scarce resources to achieve desired objectives. The model village approach could be useful in the promotion of sustainable agricultural techniques that require a community approach - involving one or more villages.

The farmer-to-farmer (or Lead Farmer) approach to agricultural extension has been employed in various forms in Malawi for the last decade. The approach was first introduced through Farmer Field Schools (FFS). Since then, the MOA and other NGOs have adopted the approach to disseminate technologies in different areas including integrated soil fertility management, conservation agriculture and IPM.

Extension Methods

DAES reaches farmers mainly through group extension methods. Extension workers mobilise farmers into groups/clubs, clusters and associations. Clusters and ulimi wa mindandandas are larger groupings based on the close proximity of their gardens to form a green belt. Some of the extension methods include the following:

- Demonstrations: extension workers use demonstrations to disseminate technologies. These are strategically placed in the communities or clusters to ensure visibility to other farmers and communities. The principle is to demonstrate one or two technologies or practices that the farmer can adopt.

- Farmer Field Schools: promoted for IPM and integrated soil fertility management techniques.

- Farmer Business Schools: used to train farmers who want to undertake farming as a business 
- Lead Farmers: DAES is also promoting the use of Lead Farmers alongside the extension workers. As of 2009, the Department had recruited over 3,000 Lead Farmers spread throughout the country. This is important because the Ministry is operating at 60\% out of the 2,880 extension worker positions available.

- Field Days: extension workers are encouraged to conduct field days for crops and livestock, among others. The principle during field days is to look at farmers holistically, that is, focus on all aspects of the household from production to processing and including utilisation.

- Agricultural shows: Farmers bring their products to show case them to others. These are held at district level.

- National Agricultural Fair: this is done in Blantyre to allow farmers to meet their buyers.

The group methods are complemented by mass media methods such as the use of the mobile vans, radio, and publications. While the mobile vans are used for specific extension campaigns, the radio and print media are used throughout the season to complement messages disseminated by extension workers in the field.

\section{GOVERNANCE STRUCTURES OF AGRICULTURAL EXTENSION AND ADVISORY SERVICES}

MOAFS Organizational Structure

MOAFS is headed by the principal secretary, who is responsible for 
Siliro Nkhukuzalira Magomero • Duk-Byeong Park / Present and Future Agricultural

two major wings: technical, and administration and finance. The technical wing is divided into agricultural institutions and technical departments. The principal secretary is supported by two controllers on technical matters and a deputy secretary on administration and financial matters. There is a controller of agricultural services (CAS) responsible for the operations of agricultural institutions such as the Agricultural Development and Marketing Corporation (ADMARC), the Agricultural Research and Extension Trust (ARET) for tobacco, smallholder crop trusts (for tea and sugar), and the Natural Resources College.

The Controller of Agricultural Extension and Technical Services (CAETS) is responsible for the proper functioning of the seven technical departments. Headed by directors, the technical departments include the following: Department of Agricultural Research Services (DARS), Department of Animal Health and Livestock (DAHL), Department of Crop Development (DCD), Department of Agricultural Extension Services (DAES), Department of Land Resources Management (DLRM), Department of Fisheries (DF), and Department of Planning (DP). All these departments work directly with the ADDs, districts, and EPAs. Each of the technical departments contributes to the main goal of improving agricultural productivity. The provision of the public agricultural extension service falls under the responsibility of DAES.

In addition, the CAETS is responsible for the operations of the ADDs, where all these technical departments are represented. The ADDs are headed by the program manager and cover two to five 
districts. With decentralization, MOAFS works through the district assemblies, which are headed by District Commissioners. In each assembly, agricultural services are under the responsibility of a district agricultural development officer (DADO), supported by a team of Subject Matter Specialists (SMSs). The DADO is basically an agricultural extension expert, although this position is not under DAES. He or she coordinates all agricultural services in the district. The SMSs are specialized extension agents who provide technical backstopping to the frontline extension workers. The public extension service is implemented through the district agricultural extension system. Each district is further subdivided into extension planning areas (EPAs), which are the basic agricultural operational or administrative units. Each EPA has a number of frontline extension workers, called agricultural extension development officers (AEDOs), who are responsible for providing extension services to smallholder farmers in a particular section of the EPA. The EPA is composed of several villages where the farmers are located.

Malawi Forum for Agricultural Advisory Services (MAFAAS) has just been institutionalized and it is an affiliate of African Forum for Agricultural Advisory Services AFAAS and it is a National Stakeholder Panel. Below are other structures related to it. 


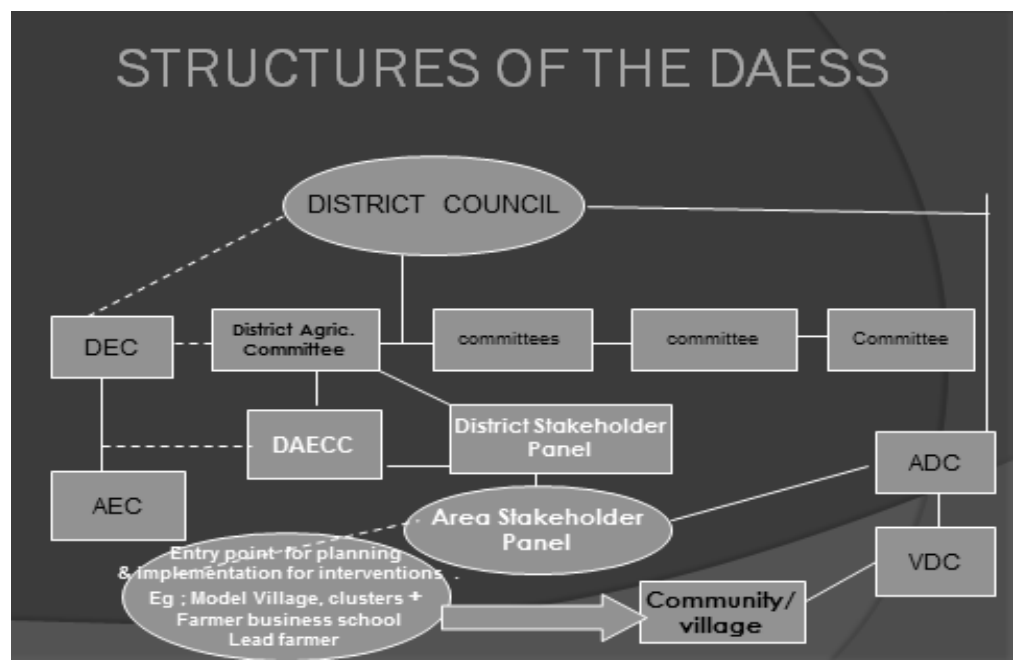

〈Fig 1〉The District Agricultural Extension Services System (DAESS)

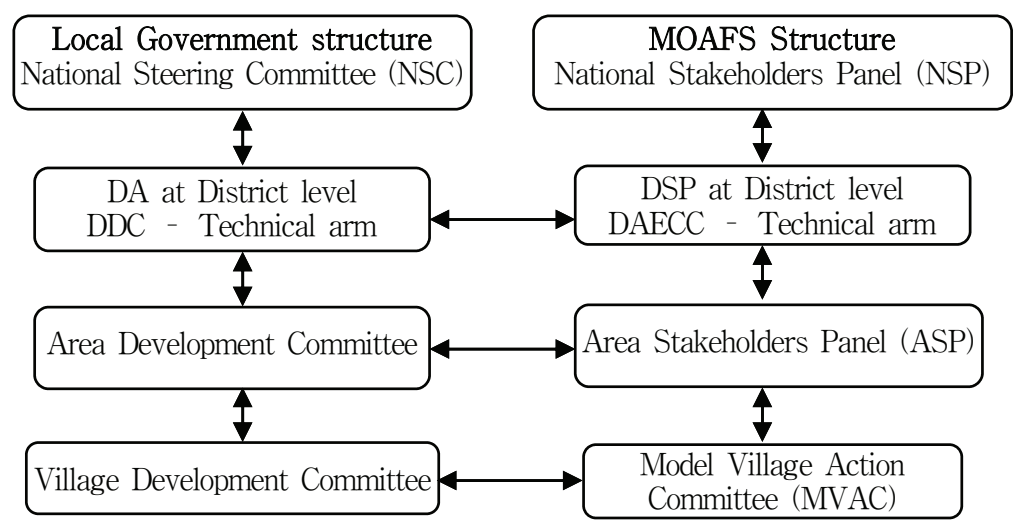

〈Fig 2〉 Linkage of Structures of the Local Government and Ministry of Agriculture and Food Security (District Agriculture Extension Services Systems - DAESS) 


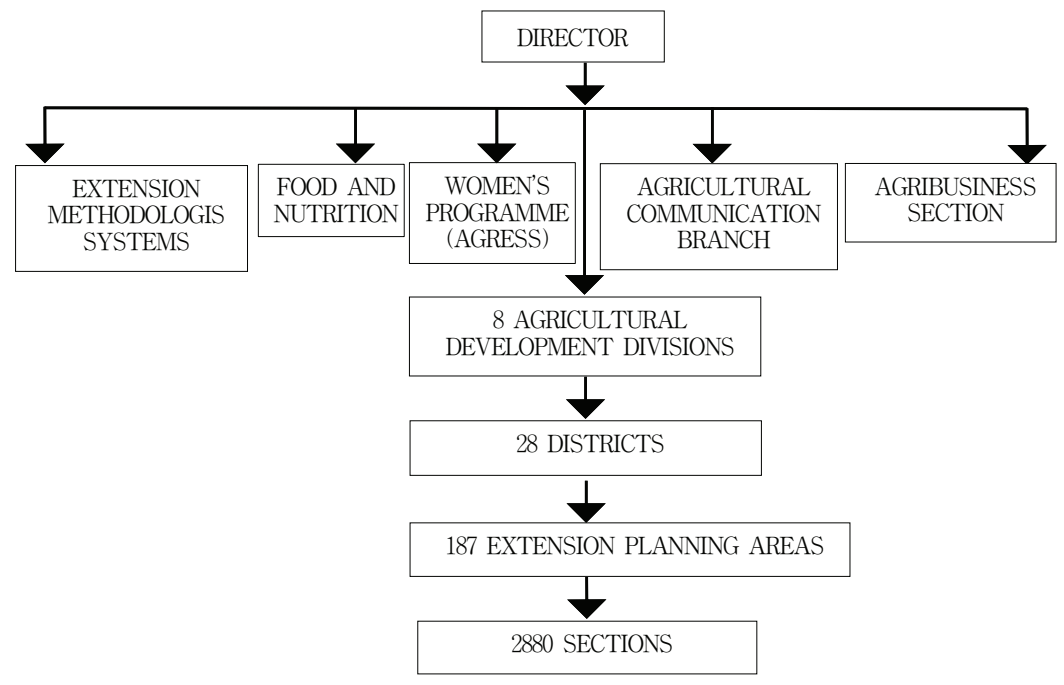

〈Fig 3〉 The Department of Agriculture Extension Services Structure

DAES implements its extension policy through the District Agricultural Extension Services System (DAESS), based on the model village approach (MOAFS, 2004). Booklets containing the guidelines for implementing the system were published and distributed to all extension staff. The guidelines stipulate that the extension system and the model village approach are aimed at promoting participatory principles for the creation of demand-driven extension services whereby farmers are empowered to identify problems and establish priorities according to their needs.

According to MOAFS (2004), the DAESS translates the extension policy into practice using two main structures: The stakeholder panels at the district and area levels and the District Agricultural Extension 
Siliro Nkhukuzalira Magomero • Duk-Byeong Park / Present and Future Agricultural

Coordinating Committee (DAECC). The two structures are tools for integrating the agricultural extension system into the district assembly. The stakeholder panel represents all actors in the agricultural sector, which include farmers, farmer organizations, and NGOs. The major roles for stakeholder panels are to provide a forum for dialogue where farmers can demand service directly from both private and public service providers and ensure that the quality and standards of the service are maintained.

These panels are facilitated by the DADO and Agricultural Extension Development Coordinator (AEDC) at the district and area levels, respectively. The district extension system has been established in all districts and, if strengthened, it has potential to develop into an effective partnership in the provision of extension in agriculture. The DAECC is critical if the pluralistic extension system is to be effective. However, the extent to which the structures are functioning is not clear. As it will be shown in this study, a lack of or poor coordination among the stakeholders is one of the challenges in the provision of extension services in Malawi.

The DAECC is comprised of DAES officials and other agricultural extension service providers in the private sector, such as NGOs and farmer organizations. Its major role is to coordinate extension service delivery in the district assembly and ensure that the quality and standards of the extension service are controlled.

The district agricultural extension system rests on four pillars (MOAFS 2004):

- Organization of farmer demand: Extension staff members are 
encouraged to organize farmers based on their categories and respond to their needs and problems accordingly. MOAFS categorizes farmers into three groups based on their resource endowments and socioeconomic status:

a) Commercial farmers (CFs): These are economically active on a large scale, with farm enterprises such as tobacco, maize (seed and food), tea, coffee, and dairy.

b) Small-scale commercial (SSC) farmers: These farmers have attained food security, possess commercial and market orientation, and are skilled in the specialist enterprises such as tobacco, horticultural crops, rice, paprika, spices, and dairy.

c) Smallholder food security (SHFS) farmers: These are farmers who possess the potential to achieve household food security from agricultural production on their farms, but due to limited land and resources are unlikely to produce a surplus for the market.

- Emphasis is on SHFS farmers, who represent 80 percent of the smallholder farmers. In view of the top-down approach that has characterized the public extension system for decades, this pillar calls for a change in attitudes by both extension staff and farmers to allow for dialogue that will facilitate a responsive, demand-driven extension system (MOAFS, 2004).

- Facilitation of service provider response: This pillar focuses on the need for the DAECC to coordinate extension services in the district and ensure that the services respond to the needs of all farmer categories. It identifies who is doing what and where in terms of extension service provision in the district and works to reach 
Siliro Nkhukuzalira Magomero • Duk-Byeong Park / Present and Future Agricultural

agreement on how best to utilize the available resources.

- Coordination and agricultural strategy development: This calls for the development of an agricultural strategy for the district in view of the many players in extension service delivery with different approaches and methods. A coordinated strategy helps minimize conflicts that may bring confusion among farmers.

- Funding acquisition: In response to dwindling public resources for the delivery of extension services, this pillar encourages extension providers to maximize the available resources from different stakeholders in the district as well as work to source more funds for the benefit of the farmers.

\section{CONCLUSION}

It will show how these influenced agricultural productivity and livelihoods of smallholder farmers. The models are: transfer of technology (TOT), Farming Systems Research and Development (Modified) TOT, and Participatory (farmer based). Although the models are discussed as distinct models, in practice, they constitute prototypes or umbrella terms that exist on a continuum based on degree of farmers' involvement in the process.

The model village approach is the major participatory approach being promoted through the District Agricultural Extension Services System. It promotes a participatory and multi-sectoral approach to planning, implementation, monitoring and evaluation of developmental 
programmes in a specific locality (one or more villages). The approach encourages staff to involve farmers in the extension process and thereby empower communities - enabling them to better articulate their demands (MOAFS, 2004).

At the national level, inappropriate public extension policies, limited public funds, lack of accountability, and growing rural poverty have prompted developing countries to re-examine the relevance of agricultural extension to rural development.

While the past extension was top-down approach, bottom - up is the present and future direction following the decentralized structures particularly the District Agriculture Extension Services System. The Model Village approach where a village is an entry point in terms of technology transfer and use of Lead Farmers are highly being promoted. 


\section{- References}

Chibwana, C. 1998. A study of the agricultural extension programme in Malawi based on the staff and farmer's perspectives. La Trobe University, Melbourne, PhD Thesis, 1998.

Government of Malawi. 2000. Agricultural Extension in the New Millennium: Towards Pluralistic and Demand-driven Services in Malawi. Lilongwe, Malawi: Department of Agricultural Extension Services, Ministry of Agriculture and Food Security.

Government of Malawi. 2006. A brief history of Agricultural Extension Services in Malawi from 1948 to 2000. Lilongwe, Malawi: Ministry of Agriculture and Food Security.

MOAFS. 2004. District agricultural extension services system implementation guide: promoting pluralistic, demand driven and decentralised agricultural extension services in Malawi.

MOAI. 2000. Agriculture in the new millennium: towards pluralistic and demand-driven services in Malawi. Policy document.

Probst, K., \& Hagmann, J. 2003. Understanding participatory research in the context of natural resource management-paradigms, approaches and typologies. ODIAGREN Network Paper No. 130. accessed $14^{\text {th }}$ November 2009.

Rhoades, R.E., \& Booth, R.H. 1982. Farmer-back-to-farmer: a model for generating acceptable agricultural technology. Agricultural Administration, 11. 127-137.

Swanson, B. E., \& Samy, M. M. 2002. Decentralization of agricultural extension systems: Key elements for success. Paper presented at the Workshop on Extension and Rural Development: A congress of View on Institutional Approaches? November, 12-15, 2002, International Food Policy Research Institute in Washington DC. 


\title{
말라위 농촌지도사업의 현재와 미래 \\ 실리로 누후쿠잘리라 마고메로 ${ }^{a}$ - 박덕병b
}

\author{
${ }^{a}$ Ministry of Agriculture and Food Security, Government of Malawi (P.O. Box 30145, \\ Lilongwe 3, Malawi, Central Africa) \\ ${ }^{b}$ Department of Community Development, Kongju National University (54 \\ Daehak-ro, Yesan-gun, Chungnam, Republic of Korea)
}

\section{초록}

말라위 농촌지도사업은 최근 농업개발에서의 부족한 기여와 소농의 요구에 부 응하지 못한 측면에서 많은 비판을 받고 있다. 그럼에도 불구하고 농촌지도사업 은 농촌생활과 농촌빈곤 문제 개선을 위해서 중시되고 있다. 말라위 농촌지도사 업은 공공부문과 민간부문에서 많은 도전을 받고 있다. 이러한 도전에 분명하고 적극적인 대응은 모든 농가들에게 편익을 제공하고 정부정책 목적을 달성하기 위한 농촌지도사업의 미래의 모습을 만드는 데 있어서 매우 중요하다. 말라위 농 촌지도사업의 당면과제는 민주주의, 시장자유화, 분권화, 에이즈, 공공자원부족, 공공부문개혁, 협력 등이다. 이를 달성하기 위하여 말라위 농촌지도사업은 복합적 인 지도사업수요를 제공해야 하고, 식량문제와 빈곤문제해결을 위하여 협력을 촉 진해야 한다. 또한 지도사업은 모델빌리지접근법(Model-village approaches)을 기 초한 지역농촌지도사업 시스템을 통하여 모든 농가들이 접근할 수 있고 질높은 지도사업 서비스를 추진해야 할 것이다.

\section{주요어 : 농촌지도, 말라위}




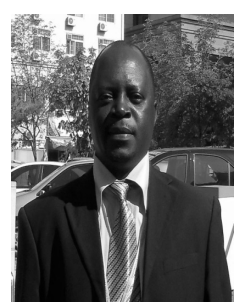

Siliro Nkhukuzalira MAGOMERO is an Agricultural Extension Methodologies Officer in the Malawi's Ministry of Agriculture and Food Security, Department of Agricultural Extension Services. He is a holder of a Bachelor of Science Degree in Agricultural Extension obtained from Bunda College of Agriculture, one of the constituent colleges of University of Malawi.

Address: Ministry of Agriculture and Food Security, Department of Agriculture Extension Services, Shire Valley Agriculture Development Division, Nsanje District Agriculture Office, P.O. Box 35, Nsanje, MALAWI

Cell: +265999228228 Email: silirmagomero@yahoo.com

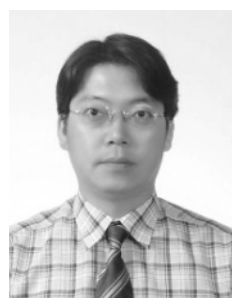

Dr. Duk-Byeong Park is an associate professor of the Department of Community Development, College of Industrial Science, Kongju National University, South Korea. His research interests are rural development, agricultural extension, rural tourism.

Address: Department of Community Development, College of Industrial Science, Kongju National University, Yesan-gun, Chungnam, 340, 702, South Korea

e-mail) parkdb84@kongju.ac.kr, phone) 82-41-330-1383 